\author{
O. Daki ${ }^{1}$, S. Herasimov ${ }^{2}$, H. Zubrytskyi ${ }^{2}$ \\ ${ }^{1}$ State University of Infrastructure and Technology, Kyiv \\ ${ }^{2}$ Ivan Kozhedub Kharkiv National Air Force University, Kharkiv
}

\title{
DIGITAL CORRELATION METHOD FOR POWER MEASUREMENT
}

The method of frequency transformations measurement for digital power of electrical signals meters is offered. The method is based on instantaneous power correlation processing. Such approach allows increasing noise immunity of the proposed method, and, as a consequence, its accuracy. Proposed mathematical theory to estimate the variance measurement error of the power of electrical signals. Proposals have been made to reduce the error in measuring the power of electrical signals. The analysis of the interference immunity of the correlation method for measuring power can be extended to the condition under which the interference spectra in voltage and current signals are different.

Keywords: method, digital power meters, noise immunity, accuracy.

\section{Introduction}

Formulation of the problem. In recent years, the requirements for the accuracy of measuring the characteristics of electric power have increased. One of the directions of creation of universal high-precision and high-speed means of power measurement is their construction on methods of digital signal processing [1-3]. However, the application of such methods is limited by the lack of applied theory for estimating their errors, and hence the synthesis of appropriate meters.

In this paper we evaluate the methodological errors of digital correlation method of power measurement: sampling and quantization errors, as well as instrumental dynamic dating error, or aperture error depending on the sampling parameters, based on the general theory of digital signal processing presented in [4]. For the certainty of the study, we estimate the methodological errors for active power, for reactive power they will be similar.

Analysis of recent research and publication. An analysis of domestic and foreign literary sources led to the conclusion that the tasks electrical signal power measurements are based on the traditional (classical) approach. This approach consists in using an intermediate functional transformation of the measured physical quantity into one unified parameter, most often into a constant voltage (or current), which is then measured by an analog or digital method [2-3; 5]. Such power meters have the following main disadvantages [5-14]. Firstly, the complexity of their hardware implementation, since each measured physical quantity (voltage, current, power, etc.) requires its own primary measuring transducer $[6 ; 8]$. This means that such devices have a high cost and low reliability, especially when operating in continuous mode.

Secondly, their relatively low accuracy, determined by the errors of analog measuring converters, which de- pend on various characteristics of the input signals (harmonic coefficient, frequency, etc.) [9; 11-12].

Thirdly, a long measurement time, since in such devices a sequential algorithm for measuring voltage and current with their analog conversion, which has a long transient time [13-14].

To a large extent, these and other disadvantages can be eliminated by the transition to a universal method for measuring various electrical quantities based on digital processing of instantaneous signal values [1518]. This method comes down to direct conversion of variable input signals (without intermediate analog conversion) at sampling points for a period into proportional codes, which are then digitally processed according to appropriate algorithms $[12 ; 17-18]$. The base for the development of the corresponding method was the work $[6 ; 12 ; 14 ; 18]$.

The aim of the paper is digital correlation method development for power measurement and the methodical error estimates.

\section{Statement of basic materials}

\section{Digital correlation method development for power measurement}

The proposed method is based on the ratio for the measured (actual) value of the active power

$$
\tilde{P}=\frac{1}{T} \int_{0}^{T} u(t) i(t) \sin (2 \omega t+\beta) d t
$$

or

$$
\tilde{P}=\frac{1}{T} \int_{0}^{T} p(t) \sin (2 \omega t+\beta) d t,
$$

where

$$
p(t)=u(t) i(t)
$$

is instantaneous power; $u(t), i(t)$ is load voltage and current in which power is measured voltage and load 
current in which power is measured; $T, \omega=\frac{2 \pi}{T}$ is the period and circular frequency of voltage and current, respectively; $\beta$ is the initial phase of the basis function (or signals) $\sin (2 \omega t+\beta)$.

Suppose that the load is linear, and the useful voltage $u_{0}(t)$ and current in it change according to a sinusoidal law:

$$
\begin{gathered}
u_{0}(t)=U_{m} \sin \omega t ; \\
i_{0}(t)=I_{m} \sin (\omega t+\varphi),
\end{gathered}
$$

where $U_{m}, I_{m}$ is maximum voltage rates $u_{0}(t)$ and current $i_{0}(t)$ accordingly; $\varphi$ is phase shift (difference) between voltage and current.

Let there be additive interference $\xi_{u}(t)$ in the voltage $i(t)$ and current curves $u(t)$ and, accordingly, uncorrelated with the main (useful) signal $u_{0}(t)$ and $i_{0}(t)$, accordingly, i.e. in the spectrum of each interference there are no components of the fundamental and multiple frequencies of this signal:

$$
\begin{gathered}
u(t)=u_{0}(t)+\xi_{u}(t) ; \\
i(t)=i_{0}(t)+\xi_{i}(t)
\end{gathered}
$$

or taking into account (3-4) we have:

$$
\begin{gathered}
u(t)=U_{m} \sin \omega t+\xi_{u}(t) ; \\
i(t)=I_{m} \sin (\omega t+\varphi)+\xi_{i}(t) .
\end{gathered}
$$

Using (5-8), from equality (2) for the real rate of the instantaneous power, we write

$$
\begin{gathered}
p(t)=U_{m} I_{m} \sin \omega t \sin (\omega t+\varphi)+ \\
+\xi_{i}(t) u_{0}(t)+\xi_{u}(t) i_{0}(t)+\xi_{u}(t) \xi_{i}(t),
\end{gathered}
$$

or

$$
p(t)=p_{0}(t)+\Delta p(t)
$$

where

$$
p_{0}(t)=U_{m} I_{m} \sin \omega t \sin (\omega t+\varphi) ;
$$

is useful instantaneous power;

$$
\Delta p(t)=\xi_{u} i_{0}(t)+\xi_{i} u_{0}(t)+\xi_{u} \xi_{i}
$$

is instantaneous power interference component $p(t)$.

In (11) and below, to shorten the entries, such forms $\xi_{u}(t) \equiv \xi_{u}, \xi_{i}(t) \equiv \xi_{i}$ was agreed.

After calculations, expression (10) takes the following form $[12 ; 19]$ :

$$
p_{0}(t)=U I \cos \phi-U I \cos (2 \omega t+\varphi),
$$

where $U, I$ is mean square, or active, voltage $u(t)$ and current values $i(t)$ accordingly.

From here we find the true value of the measured active power (excluding interference):

$$
P=\frac{1}{T} \int_{0}^{T} p_{0}(t) d t=\frac{1}{T} \int_{0}^{T}[U I \cos \phi-U I \cos (2 \omega t+\varphi)] d t .
$$

As $\int_{0}^{T} U I \cos (2 \omega t+\varphi) d t=0$, then $P=U I \cos \varphi$.

The algorithm for measuring active power by the proposed digital correlation method is based on the transition in (1) from the integral to the sum, which naturally introduces a methodological discretization error. Then for the digital equivalent, we get $N$ of the real value of the measured power $\tilde{P}$ we get

$$
\tilde{N}=\frac{1}{n} \sum_{q=1}^{n} p\left(t_{q}\right) \sin \left(2 \omega t_{q}+\beta\right) .
$$

After substituting (9) in view of (10), we have

$$
\begin{gathered}
\tilde{N}=\frac{1}{n} \sum_{q=1}^{n} U I \cos \varphi \sin \left(2 \omega t_{q}+\beta\right)- \\
-\frac{1}{n} \sum_{q=1}^{n} U I \cos \left(2 \omega t_{q}+\varphi\right) \sin \left(2 \omega t_{q}+\beta\right)+ \\
+\frac{1}{n} \sum_{q=1}^{n} \Delta p\left(t_{q}\right) \sin \left(2 \omega t_{q}+\beta\right) .
\end{gathered}
$$

In this expression, the following equalities are true:

$$
\frac{1}{n} \sum_{q=1}^{n} U I \cos \varphi \sin \left(2 \omega t_{q}+\beta\right)=0
$$

$\frac{1}{n} \sum_{q=1}^{n} U I \cos \left(2 \omega t_{q}+\varphi\right) \sin \left(2 \omega t_{q}+\beta\right)=0,5 U I \sin (\varphi-\beta)$.

Hence,

$$
\tilde{N}=\frac{1}{2} U I \sin (\varphi-\beta)+\Delta N=N+\Delta N_{\xi},
$$

where

$$
N=\frac{1}{2} U I \sin (\varphi-\beta)
$$

is Numerical equivalent of the true value of the measured active power $P$;

$$
\Delta N_{\xi}=\frac{1}{n} \sum_{q=1}^{n} \Delta p\left(t_{q}\right) \sin \left(2 \omega t_{q}+\beta\right)
$$

is Absolute power measurement error $P$, introduced by interference in voltage and current signals.

To determine the interference immunity of the method, we calculate the estimates of the interference variance $\Delta p(t)$ in the measured power $\tilde{P}$ at the input and output of the digital correlation power meter, find the signal / interference ratios for them and compare them with each other.

\section{Development of a method for calculating the interference signal when measuring power}

As can be seen from (11), the interference $\Delta p(t)$ in the instantaneous power signal is non-stationary [6], therefore, by the estimate of the variance of this interference we mean the average estimate of the variance over the signal period $T$, i.e. 


$$
\sigma_{\tilde{P}}^{2}=<\Delta p^{2}(t)>,
$$

or taking into account (11):

$$
\sigma_{\tilde{P}}^{2}=<\left[\xi_{u} i_{0}(t)+\xi_{i} u_{0}(t)+\xi_{u} \xi_{i}\right]^{2}>.
$$

For sufficiently small interference, the value $\xi_{u} \xi_{i}$ can be neglected, and, taking into account the uncorrelatedness of each interference, with the corresponding signal, we write expression (17) in the form

$$
\begin{gathered}
\sigma_{\tilde{P}}^{2}=<u_{0}^{2}(t)><\xi^{2}>+<i^{2}(t)><\xi_{u}^{2}>, \\
\sigma_{\tilde{P}}^{2}=U^{2} \sigma_{i}^{2}+I^{2} \sigma_{u}^{2},
\end{gathered}
$$

or

where

$$
\begin{gathered}
U^{2}=<u_{0}^{2}(t)>=\frac{1}{T} \int_{0}^{T} u^{2}(t) d t ; \\
I^{2}=<i_{0}^{2}(t)>=\frac{1}{T} \int_{0}^{T} i^{2}(t) d t ; \\
\sigma_{u}^{2}=<\xi_{u}^{2}>=\frac{1}{T} \int_{0}^{T} \xi_{u}^{2} d t
\end{gathered}
$$

is interference variance estimate $\xi_{u}(t)$;

$$
\sigma_{i}^{2}=<\xi_{i}^{2}>=\frac{1}{T} \int_{0}^{T} \xi_{i}^{2} d t
$$

is interference variance estimate $\xi_{i}(t)$.

We proceed to calculating the variance of the quantity $\tilde{N}$ for which, similarly to equality (16), we write

$$
\sigma_{\tilde{N}}^{2}=<\left(\Delta N_{\xi}\right)^{2}>
$$

Using expression (15), we have

$$
\sigma_{\tilde{N}}^{2}=\frac{1}{n^{2}} \sum_{q, l=}^{n} \times \sin \left(2 \omega t_{q}+\beta\right) \sin (2 \omega+\beta) .
$$

Since the interference $\xi_{u}(t), \xi_{i}(t)$ in the voltage in current signals is uncorrelated, i.e. $\left\langle\xi_{u} \xi_{i}>=0\right.$, then, taking into account equality (11), we get

$$
\begin{gathered}
<\Delta p\left(t_{q}\right) \Delta p\left(t_{l}\right)>=<\xi_{i}\left(t_{q}\right) \xi_{i}\left(t_{l}\right)>u_{0}\left(t_{q}\right) u_{0}\left(t_{l}\right)+ \\
+<\xi_{u}\left(t_{q}\right) \xi_{u}\left(t_{l}\right)>i_{0}\left(t_{q}\right) i_{0}\left(t_{l}\right) .
\end{gathered}
$$

Substituting this equality into formula (19), we have

$$
\begin{aligned}
\sigma_{\tilde{\mathrm{N}}}^{2}= & \frac{1}{\mathrm{n}^{2}} \sum_{\mathrm{q}, \mathrm{l}=1}^{\mathrm{n}} \times \sin \left(2 \omega \mathrm{t}_{\mathrm{q}}+\beta\right) \sin \left(2 \omega \mathrm{t}_{\mathrm{q}}\right) \xi_{\mathrm{i}}\left(\mathrm{t}_{1}\right)>\mathrm{u}_{0}\left(\mathrm{t}_{\mathrm{q}}\right) \mathrm{u}_{0}\left(\mathrm{t}_{1}\right) \times \\
& +\frac{1}{n^{2}} \sum_{q, l=}^{n}<\xi_{u}\left(t_{q}\right) \xi_{u}\left(t_{l}\right)>i_{0}\left(t_{q}\right) i_{0}\left(t_{l}\right) \times \\
& \left.+2 \omega t_{q}+\beta\right) \sin (2 \omega+\beta) .
\end{aligned}
$$

It can be seen from this expression that the variance $\sigma_{\tilde{N}}^{2}$ is the sum of two terms corresponding to two terms of the formula (20). Since their calculations are performed in a similar way, we will do this for one of them:
$<\left(\Delta N_{\xi}{ }^{2}>_{1}=\frac{1}{n^{2}} \sum_{q, l=}^{n} \begin{array}{l}<\xi_{i}\left(t_{q}\right) \xi_{i}\left(t_{l}\right)>u_{0}\left(t_{q}\right) u_{0}\left(t_{l}\right) \times \\ \times \sin \left(2 \omega t_{q}+\beta\right) \sin (2 \omega+\beta) .\end{array}\right.$

The quantity $<\xi_{i}\left(t_{q}\right) \xi_{i}\left(t_{l}\right)>$ is the correlation function of the disturbance in the current curve. For stationary interference, the correlation function depends only on the modulus of the time difference $t_{q}$ and $t_{l}[6 ; 19]$ :

$$
<\xi_{i}\left(t_{q}\right) \xi_{i}\left(t_{l}\right)>=R_{i}\left(t_{q}, t_{l}\right)=R_{i}\left(\left|t_{q}-t_{l}\right|\right),
$$

where $R_{i}\left(t_{q}, t_{l}\right)=R_{i}\left(\left|t_{q}-t_{l}\right|\right)$ - stationary interference correlation function.

Let us first consider the simplest case, when the values of the noise $\xi_{i}(t)$ at different times $t_{q}, t_{l}$ are uncorrelated, i.e.

$$
<\xi_{i}\left(t_{q}\right) \xi_{i}\left(t_{l}\right)>=\left\{\begin{array}{rll}
\sigma_{i}^{2} & \text { at this } t_{q}=t_{l} \\
& \text { at this } t_{q} \neq t_{l} .
\end{array}\right.
$$

Taking this expression into account we get

$$
<\left(\Delta N_{\xi}\right)^{2}>=\frac{\sigma_{i}^{2}}{n^{2}} \sum_{q=1}^{n} u_{0}^{2}\left(t_{q}\right) \sin ^{2}(2 \omega t+\beta) .
$$

Substituting equality (3), we get

$$
<\left(\Delta N_{\xi}\right)^{2}>_{1}=\frac{\sigma_{i}^{2} U_{m}^{2}}{n^{2}} \sum_{q=1}^{n} \sin ^{2} \omega t_{q} \cdot \sin ^{2}\left(2 \omega t_{q}+\beta\right) \text {. }
$$

After trigonometric transformations, taking into account [20], we find

$$
\begin{gathered}
<\left(\Delta N_{\xi}{ }^{2}>_{1}=\frac{\sigma_{i}^{2} U_{m}^{2}}{4 n^{2}}\left\{\sum_{q=1}^{n} \times\left[1-\cos 2 \omega t_{q}\right) \times\right.\right. \\
<\left(\Delta N_{\xi}{ }^{2}>_{1}=\frac{1}{2 n} \sigma_{i}^{2}{ }^{2} .\right.
\end{gathered}
$$$$
\text { or }
$$

Similar calculations of the second term in formula (21) give

$$
<\left(\Delta N_{\xi}{ }^{2}>_{2}=\frac{1}{2 n} \sigma_{u}^{2}{ }^{2} .\right.
$$

Summing up the two components of the variance $\sigma_{N}^{2}$ given by equalities (23) and (24), for the condition of uncorrelated interference, we obtain

$$
\sigma_{\tilde{N}}^{2}=\frac{1}{2 n}\left(\sigma_{i}^{2} U^{2}+\sigma_{u}^{2} I^{2}\right) \text {. }
$$

Let us calculate the signal-to-interference ratio at the input and output of the digital correlation power meter, taking the power / variance fraction as the indicator of this ratio. Using expressions (13), (14), (18) and (26) for the most unfavorable phase ratio, we find the maximum values of the signal-to- interference ratio:

- at the input of the power meter

$$
\left(\frac{U^{2} I^{2}}{\sigma_{\tilde{P}}^{2}}\right)_{\max }=\frac{U^{2} I^{2}}{\sigma_{u}^{2} I^{2}+\sigma_{i}^{2} U^{2}}
$$

- at the output of the power meter 


$$
\left(\frac{N^{2}}{\sigma_{\tilde{N}}^{2}}\right)_{\max }=\frac{U^{2} I^{2} n}{2\left(\sigma^{2} I^{2}+\sigma_{i}^{2} U^{2}\right)} .
$$

We introduce the ratio

$$
k_{i m}=\left(\frac{N^{2}}{\sigma_{\tilde{N}}^{2}}\right)_{\max } /\left(\frac{U^{2} I^{2}}{\sigma_{\tilde{P}}^{2}}\right)_{\max } .
$$

The ratio (29) is the coefficient of interference immunity.

Substituting equalities (27), (28) into formula (29), we have

$$
k_{i m}=\frac{n}{2},
$$

i.e. the signal-to-interference ratio at the output of the correlation power meter is $n / 2$ times greater than the signal-to-interference ratio at its input. Thus, the interference immunity of the digital correlation method for measuring power, provided that the interference in the voltage and current curves is uncorrelated, is determined by the number of sampling points $n$.

Let us now consider the general case when interference in voltage and current signals are correlated.

Let us express the dispersion component $<\left(\Delta N_{\xi}\right)^{2}>_{1}$ in terms of the correlation function, for this we substitute (3) and (23) into formula (22), we obtain.

$$
<\left(\Delta N_{\xi}{ }^{2}>_{1}=\frac{U_{m}^{2}}{n^{2}} \sum_{, l=1 \times \sin \left(2 \omega t_{q}+\beta\right) \sin (2 \omega+\beta) .}^{R_{i}\left(\left|t_{q}-t_{l}\right|\right) \sin \omega t_{q} \sin \omega t_{l} \times} .\right.
$$

Let us denote the spectral power density (PSD) of the interference $\xi_{i}(t)$ through $G_{i}(\Omega)$. In accordance with the Wiener-Khinchin's theorem [19-20]:

$$
R_{i}(\tau)=\int_{-\infty}^{\infty} G_{i}(\Omega) e^{j \Omega \tau} d \Omega
$$

where $\tau$ is time shifting.

After conversion we will write down

$$
\begin{aligned}
& <\left(\Delta N_{\xi}{ }^{2}>_{1}=\frac{U_{m}^{2}}{n^{2}} \times\right.
\end{aligned}
$$

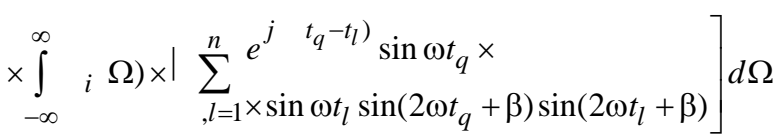

or

$$
<\left(\Delta N_{\xi}\right)^{2}>_{1}=\frac{U_{m}^{2}}{n^{2}} \int_{-\infty}^{\infty} G_{i}(\Omega)|\chi(\omega, \Omega)|^{2} d \Omega,
$$

where the following is indicated

$$
\begin{gathered}
\chi(\omega, \Omega)=\sum_{q=1}^{n} e^{j \Omega t_{q}} \sin \omega t \sin \left(2 \omega t_{q}+\beta\right)= \\
=\sum_{l=1}^{n} e^{j \Omega t_{l}} \sin \omega t_{l} \sin \left(2 \omega t_{l}+\beta\right) .
\end{gathered}
$$

The physical meaning of the function $\chi(\omega, \Omega)$ is explained below.

Let us calculate the function $\chi(\omega, \Omega)$ after transforming it to the form

$$
\chi(\omega, \Omega)=\frac{1}{2} \sum_{q=1}^{n} e^{j \Omega t_{q}}\left[\cos \left(\omega t_{q}+\beta\right)-\cos \left(3 \omega t_{q}+\beta\right)\right] .
$$

Using the formula [19]:

$$
\cos x=\frac{1}{2}\left(e^{j x}+e^{-j x}\right)
$$

we get

$$
\left.\chi(\omega, \Omega)=\frac{1}{4} \sum_{q=1}^{n} e^{j \Omega t_{q}} \mid \begin{array}{c}
e^{j \omega t_{q}+j \beta}+e^{-j \omega t-j \beta}- \\
e^{j 3 \omega t_{q}+j \beta}-e^{-j \omega t_{q}-j \beta}
\end{array}\right)
$$

or

$$
\chi(\omega, \Omega)=\frac{1}{4}\left[\chi_{1}(\omega, \Omega)+\chi_{2}(\omega, \Omega)-\chi_{3}(\omega, \Omega)-\chi_{4}(\omega, \Omega)\right],
$$

where

$$
\begin{aligned}
& \chi_{1}(\omega, \Omega)=\sum_{1}^{n} e^{j(\Omega+\omega) t_{q}+j \beta}=e^{j \beta}{ }_{q=1}^{n} e^{j(\Omega+\omega) q \Delta t} ; \\
& \chi_{2}(\omega, \Omega)=\sum_{1}^{n} e^{j(\Omega-\omega) t_{q}-j \beta}=e^{-j \beta}{ }_{q=1}^{n} e^{j(\Omega-\omega) q \Delta t} ; \\
& \chi_{3}(\omega, \Omega)=\sum_{1}^{n} e^{j(\Omega+3 \omega) t_{q}+j \beta}=e^{j \beta}{ }_{q=1}^{n} e^{j(\Omega+3 \omega) q \Delta t} ; \\
& \chi_{4}(\omega, \Omega)=\sum_{1}^{n} e^{j(\Omega-3 \omega) t_{q}-j \beta}=e^{-j \beta}{ }_{q=1}^{n} e^{j(\Omega-3 \omega) q \Delta t}
\end{aligned}
$$

In these equalities the following are accepted

$$
t_{q}=q \Delta t
$$

is moments (points) of signal sampling;

$$
\Delta t=\frac{T}{n}=\frac{2 \pi}{n \omega}
$$

is signal sampling interval (step).

Let's calculate the functions $\chi_{1}(\omega, \Omega), \chi_{2}(\omega, \Omega)$, $\chi_{3}(\omega, \Omega), \chi_{4}(\omega, \Omega)$.

These calculations are similar and are based on the fact that the sums in expressions (34) - (37) are geometric progressions. Therefore, we will use the formula for the sum of a geometric progression [19-20]:

$$
S=a \frac{1-r^{n}}{1-r},
$$

where $a, r, n$ is first term, denominator and number of members of the progression, accordingly.

As can be seen from expression (34), for the function $\chi_{1}(\omega, \Omega)$ we have

$$
a=r=e^{j(\Omega+\omega) \Delta t} .
$$

Substituting equality (40) into formula (39), we obtain

$$
S_{1}(\omega, \Omega)=e^{j(\Omega+\omega) \Delta t} \frac{1-e^{j(\Omega+\omega) n \Delta t}}{1-e^{j(\Omega+\omega) \Delta t}} .
$$

Taking this ratio into account, formula (34) takes 
the form

$$
\chi_{1}(\omega, \Omega)=e^{j \beta} e^{j(\Omega+\omega) \Delta t} \frac{1-e^{j(\Omega+\omega) n \Delta t}}{1-e^{j(\Omega+\omega) \Delta t}} .
$$

Considering the equality

$$
j \omega n \Delta t=e^{j 2 \pi}=1
$$

we find

$$
\chi_{1}(\omega, \Omega)=e^{j \beta+j(\Omega+\omega) \Delta t} \frac{1-e^{j n \Omega \Delta t}}{1-e^{j(\Omega+\omega) \Delta t}} .
$$

Similarly, we get:

$$
\begin{aligned}
& \chi_{2}(\omega, \Omega)=e^{-j \beta+j(\Omega-\omega) \Delta t} \frac{1-e^{j n \Omega \Delta t}}{1-e^{j(\Omega-\omega) \Delta t}} ; \\
& \chi_{3}(\omega, \Omega)=e^{j \beta+j(\Omega+3 \omega) \Delta t} \frac{1-e^{j n \Omega \Delta t}}{1-e^{j(\Omega+3 \omega) \Delta t}} ; \\
& \chi_{4}(\omega, \Omega)=e^{-j \beta+j(\Omega-3 \omega) \Delta t} \frac{1-e^{j n \Omega \Delta t}}{1-e^{j(\Omega-3 \omega) \Delta t}} .
\end{aligned}
$$

After substituting expressions (41) - (44) into formula (33), we have

$$
\begin{gathered}
\chi(\omega, \Omega)=\frac{1}{4} e^{j \Omega \Delta t}\left(1-e^{j n \Omega \Delta t}\right)\left[e^{j \beta} \frac{e^{j \omega \Delta t}}{1-e^{j(\Omega+\omega) \Delta t}}+\right. \\
+-j \beta \frac{e^{-j \omega \Delta t}}{-e^{j(\Omega-\omega) \Delta t}}-e^{\beta} \frac{e^{j 3 \omega \Delta t}}{1-e^{j(\Omega+3 \omega) \Delta t}}- \\
-e^{-j \beta} \frac{e^{-j 3 \omega \Delta}}{1-e^{j(\Omega-3 \omega) \Delta t}}
\end{gathered}
$$

Note that the denominators of the second and fourth terms in straight brackets of this formula vanish at frequencies $\Omega=\frac{2 k \pi}{\Delta t} \pm \omega$ and $\Omega=\frac{2 k \pi}{\Delta t} \pm 3 \omega$ $k=0,1,2,3, \ldots$, respectively. It is these points that make the main contribution to the integration in expression (31). Since near each such point, only one of the terms of formula (45) is essential, the cross terms can be omitted when calculating the modulus $|\chi(\omega, \Omega)|^{2}$. Considering also the equality [18-19]:

$$
\left|e^{j x}\right|^{2}=\left|e^{-j x}\right|^{2}=\left|e^{j x} e^{-j x}\right|=1,
$$

we get

$$
\begin{gathered}
|\chi(\omega, \Omega)|^{2}=\frac{1}{16}\left|1-e^{j n \Omega \Delta t}\right|^{2}\left[\frac{1}{\left|e^{-j \omega \Delta t}-e^{j \Omega \Delta t}\right|^{2}}+\right. \\
\left.+\frac{1}{\left|e^{j \omega \Delta t}-e^{j \Omega \Delta t}\right|^{2}}+\frac{1}{\left|e^{ \pm j 3 \omega \Delta t}-e^{j \Omega \Delta t}\right|^{2}}\right]
\end{gathered}
$$

Let's calculate the squares of the modules in this formula. To do this, we represent them as a product of complex conjugate quantities, for example, according to the expression.

Further, using Euler's formula [19]:

$$
e^{ \pm j x}=\cos x \pm j \sin x,
$$

after transformations we have

$$
\left|{ }^{\alpha}-e^{-j \beta}\right|^{2}=4 \cos ^{2} \frac{(\alpha+\beta)}{2} .
$$

Making similar calculations for all squared moduli in relations $(41)-(44)$, we find

$$
\begin{gathered}
\left|1-e^{j n \Omega \Delta t}\right|^{2}=4 \sin ^{2} \frac{n \Omega \Delta t}{2} ; \\
\left|e^{-j \omega \Delta t}-e^{j \Omega \Delta t}\right|^{2}=4 \sin ^{2} \frac{(\Omega+\omega) \Delta t}{2} ; \\
\left|e^{j \omega \Delta t}-e^{j \Omega \Delta t}\right|^{2} \quad 4 \sin ^{2} \frac{(\Omega-\omega) \Delta t}{2} ; \\
\left|-j \omega \Delta t-e^{j \Omega \Delta t}\right|^{2}=4 \sin ^{2} \frac{(\Omega+3 \omega) \Delta t}{2} ; \\
\left|j \omega \Delta t-e^{j \Omega \Delta t}\right|^{2}=4 \sin ^{2} \frac{(\Omega-3 \omega) \Delta t}{2} .
\end{gathered}
$$

After substituting equalities (46) - (50) into formula (48), we obtain

$$
\begin{aligned}
& |\chi(\omega, \Omega)|^{2}=\frac{1}{16} \sin ^{2} \frac{n \Omega \Delta t}{2}\left[\frac{1}{\sin ^{2} \frac{(\Omega+\omega) \Delta t}{2}}+\right. \\
& \left.+\frac{1}{\sin ^{2} \frac{(\Omega-\omega) \Delta t}{2}}+\frac{1}{\sin ^{2} \frac{(\Omega+3 \omega) \Delta t}{2}}+\frac{1}{\sin ^{2} \frac{(\Omega-3 \omega) \Delta t}{2}}\right] .
\end{aligned}
$$

For the values $\Omega>0$ in parentheses of this expression, only two terms (the second and fourth) can be left and the other two (the first and third) can be neglected:

$$
|\chi|_{+}^{2}=\frac{1}{16} \sin ^{2} \frac{n \Omega \Delta t}{2} \frac{1}{\sin ^{2} \frac{(\Omega-\omega) \Delta t}{2}}+\frac{1}{\sin ^{2} \frac{(\Omega-3 \omega) \Delta t}{2}} \mid .
$$

As can be seen from this equality, at large, the function $|\chi|_{+}^{2}$ has pronounced filtering properties, so that in the integral of formula (31) all components of the interference will be filtered (suppressed), the frequency of which does not satisfy these two conditions:

$$
\begin{aligned}
& \Omega_{k}=\frac{2 k \pi}{\Delta t}+\omega ; \\
& \Omega_{k}^{\prime}=\frac{2 k \pi}{\Delta t}+3 \omega .
\end{aligned}
$$

Obviously, it is precisely the narrow-band filtering properties of the function $\chi(\omega)$ that explain the advantage of the correlation method for measuring power, which includes its high interference immunity. Therefore, the function $\chi(\omega)$ can be called filtering. Let us confirm what was said above more explicitly; in this case, we turn to the expression (31). But first, from the Wiener-Khinchin's theorem (30), taking into account the equality $\sigma_{i}^{2}=R_{i}(0)$, we write 


$$
\sigma_{i}^{2}=\int_{-\infty}^{\infty} G(\Omega) d \Omega .
$$

Then the corresponding component of the error in formula (18) is

$$
\sigma_{P i}^{2}=U^{2} \sigma_{i}^{2}=U^{2} \int_{-\infty}^{\infty} G_{i}(\Omega) d \Omega .
$$

From a comparison of expressions (31) and (54), it can be seen that the function $|\chi(\omega, \Omega)|^{2}$ plays the role of the noise transmission coefficient in terms of power from the input to the output at the frequency $\Omega$. Therefore, indeed, the filtering properties of the function $|\chi(\Omega)|^{2}$ ensure the noise immunity of the proposed correlation method for measuring power.

Quantitative estimates of the interference immunity of the method depend on the energy distribution over the interference spectrum, i.e. on the type of interference $G_{i}(\Omega)$ SPM. Obviously, these estimates will be determined by the ratio between the bandwidth of the interference spectrum $\xi_{i}(t)$ and the bandwidth of the filter function $|\chi(\Omega)|_{+}^{2}$. Let's show it.

To make the calculations clearer, we qualitatively depict the function curve $|\chi(\Omega)|_{+}^{2}$. This curve has main and side maxima (Fig. 1). The main maxima of the curve (and function $|\chi(\Omega)|_{+}^{2}$ ) are found at the frequency $\Omega$ values determined by the interactions between (51) and (56). Since according to equality (38) we have

$$
\frac{2 \pi}{\Delta t}=n \omega \text {. }
$$

Later, the following expressions (51), (52) can be represented as

$$
\begin{gathered}
\Omega_{k}=\omega+k n \omega=(1+k n) \omega ; \\
\Omega_{k}^{\prime}=3 \omega+k n \omega=(3+k n) \omega \text { if } k=0,1,2, \ldots .
\end{gathered}
$$

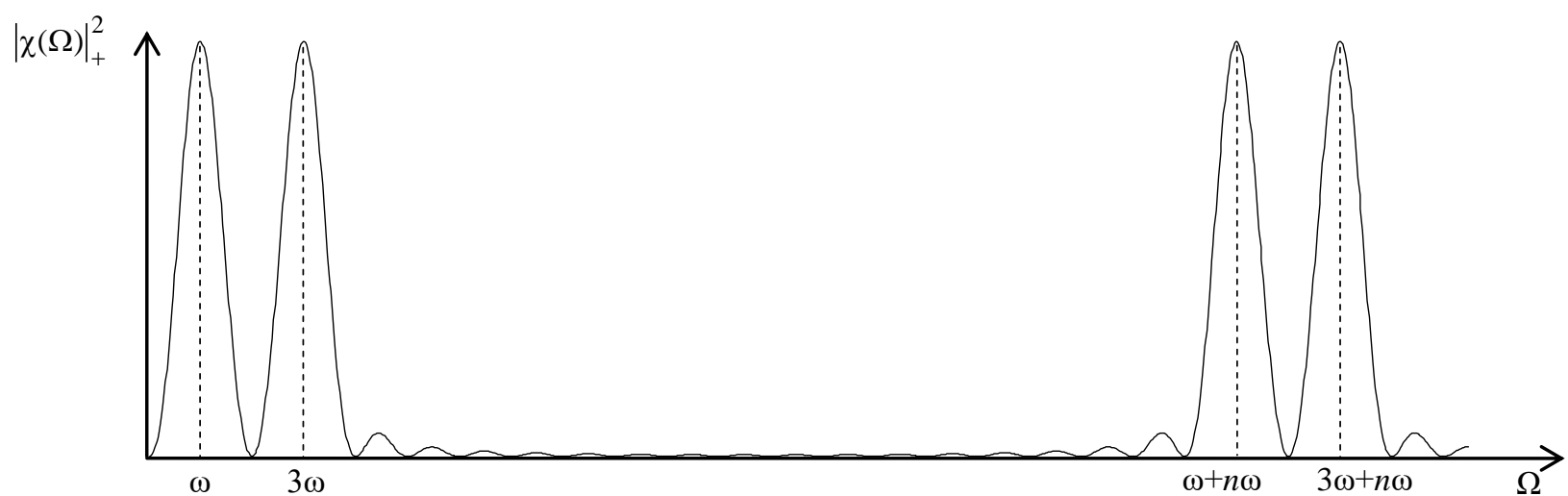

Fig. 1. Main and side maxima

The value of the function $|\chi(\Omega)|_{+}^{2}$ at the main maxima can be found by passing to the limit. It is equal

$$
\max |\chi(\Omega)|_{+}^{2}=\frac{n^{2}}{16}
$$

The widths of all major maxima are the same and equal in order of magnitude $\Delta \Omega \approx \omega$.

Between the main maxima of the function $|\chi(\Omega)|_{+}^{2}$, there are many of its side maxima at frequency values $\Omega$ that satisfy the condition

$$
\frac{n \Omega \Delta t}{2}=(2 m+1) \frac{\pi}{2},
$$

when $\Omega_{m}=\left(m+\frac{1}{2}\right) \omega$ if $m=0,1,2, \ldots$.

However, the amplitudes of the side maxima of the function $|\chi(\Omega)|_{+}^{2}$ decrease very quickly as they move away from the main maxima.
The most unfavorable in terms of interference immunity of the method is the case when the interference spectrum overlaps

with the curve $\mid \chi\left(\left.\Omega\right|_{+} ^{2}\right.$, i.e. part of the interference spectrum falls into the region of the main maxima of the function curve $|\chi(\Omega)|_{+}^{2}$.

Let us consider this case, denoting the interference spectrum width. Three options may appear here:

- broadband interference $(\Delta \Omega>>\omega)$;

- narrowband interference $(\Delta \Omega<<\omega)$;

- the interference is narrowband, and its center frequency is near the frequencies $\omega$ or $3 \omega$.

Option 1. Broadband interference $(\Delta \Omega>>\omega)$.

Assume for definiteness that the interference spectrum is in the region of the first main maximum of the function $|\chi(\Omega)|_{+}^{2}$ (Fig. 2). 


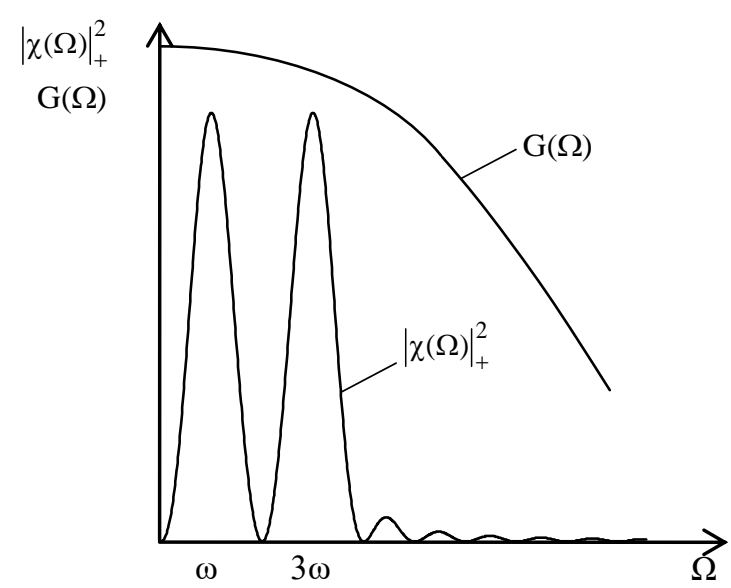

Fig. 2. The interference spectrum

Within the main maxima, the interference spectrum can be approximately considered constant, i.e. $G_{i}(\Omega) \approx G_{i}^{o}$. In this case, to estimate the variance of the interference $\sigma_{i}^{2}$ from expression (53), we obtain

$$
\sigma_{i}^{2}=\int_{-\Delta \Omega}^{\Delta \Omega} G_{i}^{o} d \Omega \approx 2 G_{i}^{o} \Delta \Omega,
$$

and we transform formula (31) to the form

$$
\begin{gathered}
<\left(\Delta N_{\xi}{ }^{2}>_{1}=\frac{U_{m}^{2} G_{i}^{o}}{n^{2}} \times\right. \\
\times \quad|\chi(\omega, \Omega)|^{2} d \Omega=\frac{2 U_{m}^{2} G_{i}^{o}}{n^{2}} \int_{0}^{\Delta \Omega}|\chi(\Omega)|^{2} d \Omega .
\end{gathered}
$$

Taking into account equality (31), we have

$$
<\left(\Delta N_{\xi}{ }^{2}>_{1} \approx \frac{U_{m}^{2} G_{i}^{o}}{8 n^{2}} \times\right.
$$$$
\times \int_{0}^{\Delta \Omega} \sin ^{2} \frac{n \Omega \Delta t}{2}\left[\frac{1}{\sin ^{2} \frac{(\Omega-\omega) \Delta t}{2}}+\frac{1}{\sin ^{2} \frac{(\Omega-3 \omega) \Delta t}{2}}\right] d \Omega .
$$

We change the variables here $\Omega-\omega=\Omega^{\prime}$ and $\Omega-3 \omega=\Omega^{\prime}$, we obtain

$$
<\left(\Delta N_{\xi}\right)^{2}>_{1} \approx \frac{U_{m}^{2} G_{i}^{o}}{8 n^{2}}\left(\begin{array}{c}
\int_{-\omega}^{\Delta \Omega-\omega} \frac{\sin ^{2} \frac{n \Omega^{\prime} \Delta t}{2}}{\sin ^{2} \frac{\Omega^{\prime} \Delta t}{2}} d \Omega^{\prime}+ \\
+\int_{-3 \omega}^{\Delta \Omega-3 \omega} \frac{\sin ^{2} \frac{\Omega^{\prime} \Delta t}{2}}{\sin ^{2} \frac{\Omega^{\prime} \Delta t}{2}} d \Omega^{\prime}
\end{array}\right)
$$

Since the width $\Delta \Omega$ of the curve of a function $|\chi(\omega, \Omega)|^{2}$ is approximately of the order of magnitude $\Delta \Omega \sim \omega$, and its height is $\max |\chi(\omega, \Omega)|^{2} \sim n^{2}$, then both integrals in formula (57) are equal in order of magnitude $\Delta \Omega \max |\chi|^{2} \sim \omega n^{2}$. Taking this into account, expression (57) approximately takes the form or

$$
\begin{gathered}
<\left(\Delta N_{\xi}\right)^{2}>_{1} \sim \frac{2 U^{2} G_{i}^{o}}{8 n^{2}} 2 \omega^{2}, \\
<\left(\Delta N_{\xi}\right)^{2}>_{1} \sim a U^{2} G_{i}^{o} \omega,
\end{gathered}
$$

where $a$ is numerical coefficient of the order of unity.

Substituting equality (31) into formula (57), we

$$
<\left(\Delta N_{\xi}{ }^{2}>_{1} \approx a U^{2} \sigma_{i}^{2} \frac{\omega}{\Delta \Omega} .\right.
$$

Assuming the same width of the interference spectrum $\xi_{u}(t)$ in the voltage signal, we write

$$
<\left(\Delta N_{\xi}{ }^{2}>_{2} \approx a I^{2} \sigma_{u}^{2} \frac{\omega}{\Delta \Omega} .\right.
$$

Then, to estimate the variance of the power measurement error

$$
\sigma_{N}^{2}=<\left(\Delta N_{\xi}\right)^{2}>=<\left(\Delta N_{\xi}\right)^{2}>_{1}+<\left(\Delta N_{\xi}\right)^{2}>_{2} .
$$

After substituting equalities (63), (64), we obtain

$$
\sigma_{N}^{2} \approx a \frac{\omega}{\Delta \Omega}\left(\sigma_{i}^{2} U^{2}+\sigma_{u}^{2} I^{2}\right),
$$

or taking into account the relation (18):

$$
\sigma_{N}^{2} \approx<\left(\Delta N_{\xi}{ }^{2}>a \frac{\omega}{\Delta \Omega} \sigma^{2} .\right.
$$

Using formula (29), we find the coefficient of interference immunity. For this, we substitute expression (61) into (29), and also, bearing in mind that according to formula (14) $\mathrm{N} \approx \mathrm{UI}$, we obtain

$$
k_{i m} \approx \frac{\Delta \Omega}{\omega} .
$$

Thus, for broadband interference, for which the condition $\Delta \Omega>>\omega$ is valid, the interference immunity coefficient of the correlation method for measuring the power according to equality (62)

$$
k_{\text {im }}>>1 \text {, }
$$

i.e. there is, as expected, a very high interference immunity. Obviously, it is provided by a sharp narrowing of the effective band of the interference spectrum and due to the filtering function $|\chi(\omega, \Omega)|^{2}$.

Option 2. Narrowband interference $\Delta \Omega<<\omega$, and the center frequency of the interference spectrum $\Omega_{0}$ satisfy the condition $\Omega_{0} \neq \omega$ (Fig. 3).

For such a disturbance in expression (31), we can move the function $\mid \chi\left(\left.\Omega_{0}\right|_{+} ^{2}\right.$ out from under the integral, and then we have

$$
\begin{gathered}
<\left(\Delta N_{\xi}\right)^{2}>_{1}=\frac{U_{m}^{2}}{n^{2}}|\chi(\Omega)|_{+}^{2} \int_{-\infty}^{\infty} G_{i}(\Omega) d \Omega, \\
<\left(\Delta N_{\xi}\right)^{2}>=\frac{2 U^{2} \sigma_{i}^{2}}{n^{2}}\left|\chi\left(\Omega_{0}\right)\right|_{+}^{2} .
\end{gathered}
$$

Similarly, we get

$$
<\left(\Delta N_{\xi}\right)^{2}>=\frac{2 I^{2} \sigma_{u}^{2}}{n^{2}}\left|\chi\left(\Omega_{0}\right)\right|^{2} .
$$




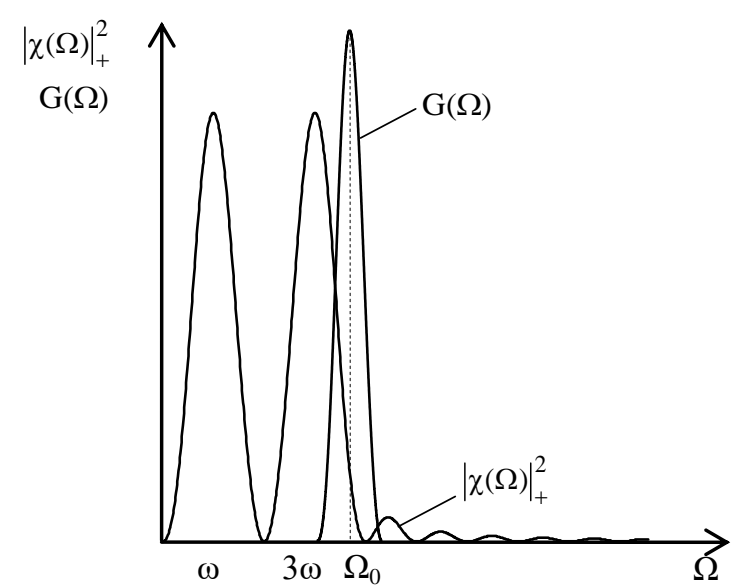

Fig. 3. The center frequency of the spectrum

Then the estimate of the variance of the power measurement error

$$
\begin{gathered}
<\left(\Delta N_{\xi}\right)^{2}>=<\left(\Delta N_{\xi}\right)^{2}>+<\left(\Delta N_{\xi}\right)^{2}>_{2}= \\
=\frac{2}{n^{2}}\left(\sigma^{2} U^{2}+\sigma_{u}^{2} I^{2}\right)\left|\chi\left(\Omega_{0}\right)\right|^{2},
\end{gathered}
$$

or taking into account equality (18):

$$
<\left(\Delta N_{\xi}\right)^{2}>=\frac{2 \sigma_{P}^{2}}{n^{2}}\left|\chi\left(\Omega_{0}\right)\right|^{2} .
$$

For the interference immunity coefficient from the formula (29), taking into account equalities (14) and (63), we obtain

$$
k_{i m} \approx \frac{n^{2}}{8\left|\chi\left(\Omega_{0}\right)\right|^{2}} .
$$

If the center frequency of the interference $\Omega_{0}$ is far enough from the frequencies $\omega=\Omega$ and $\omega=3 \Omega$, then

$$
\left|\chi\left(\Omega_{0}\right)\right|^{2}<<\max |\chi(\Omega)|^{2}=\frac{n^{2}}{16} .
$$

Therefore, for a given narrowband interference, the interference immunity coefficient $k_{i m}>>1$, so that the method has a sufficiently high interference immunity.
Option 3. The interference is narrowband $\Delta \Omega<<\omega$, and the center frequency $\Omega_{0}$ is near the frequencies $\omega$ or $3 \omega$ (Fig. 4).

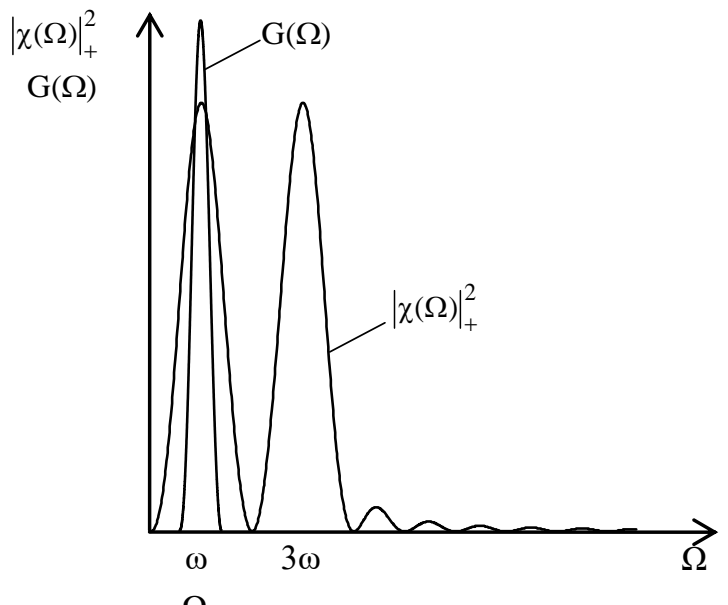

Fig. 4. The interference is narrowband

Repeating the calculations of option 2, for the interference immunity coefficient we obtain

$$
k_{i m} \approx \frac{n^{2}}{4\left|\chi\left(\omega_{1}\right)\right|^{2}},
$$

where $\omega_{1} \approx \omega$ or $\omega_{1} \approx 3 \omega$.

Wherein

$$
\left|\chi\left(\omega_{1}\right)\right|^{2} \approx \max |\chi(\Omega)|^{2} .
$$

Taking into account equality (62), for the interference immunity coefficient it is approximately possible to take $k_{\text {im }} \sim 1$.

Thus, with a narrow-band interference $\Delta \Omega<<\omega$, the central frequency of which is near frequencies $\omega$ and $3 \omega$, the interference immunity of the method is practically absent.

Let us now consider a special case when the interference spectrum does not overlap with the function $|\chi(\Omega)|^{2}$, i.e. the interference spectrum is located far from the frequencies $\omega, 3 \omega, \omega+n \omega$ and $3 \omega+n \omega$ (Fig. 5-6).

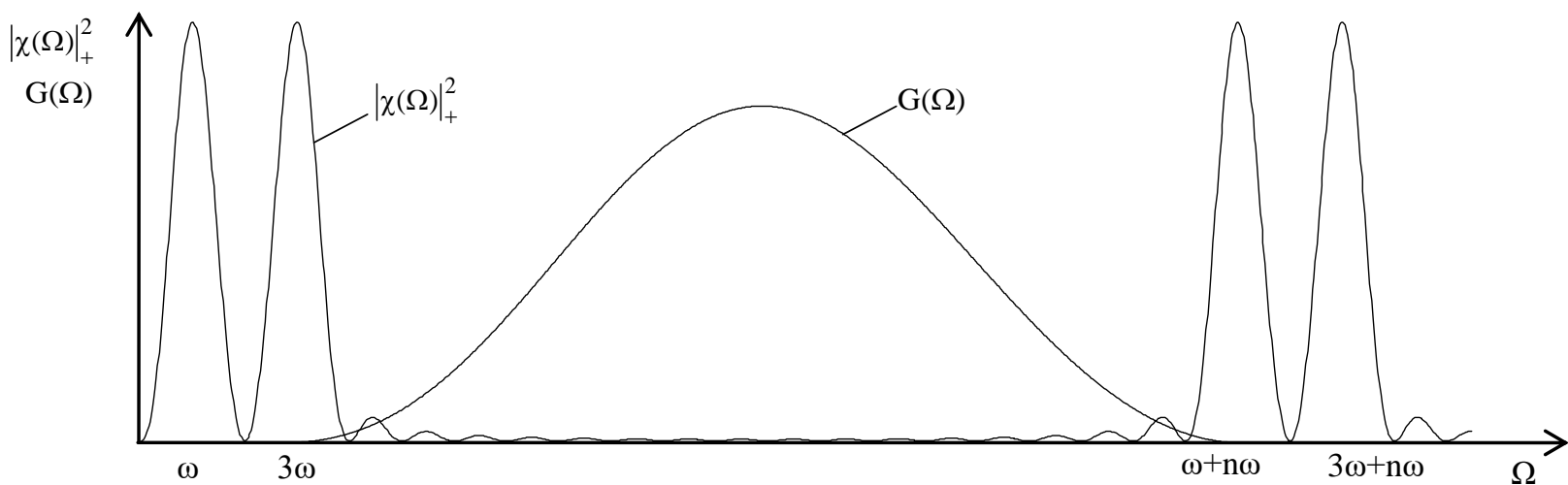

Fig. 5. The interference spectrum is located from the frequencies $\omega, 3 \omega, \omega+n \omega$ 


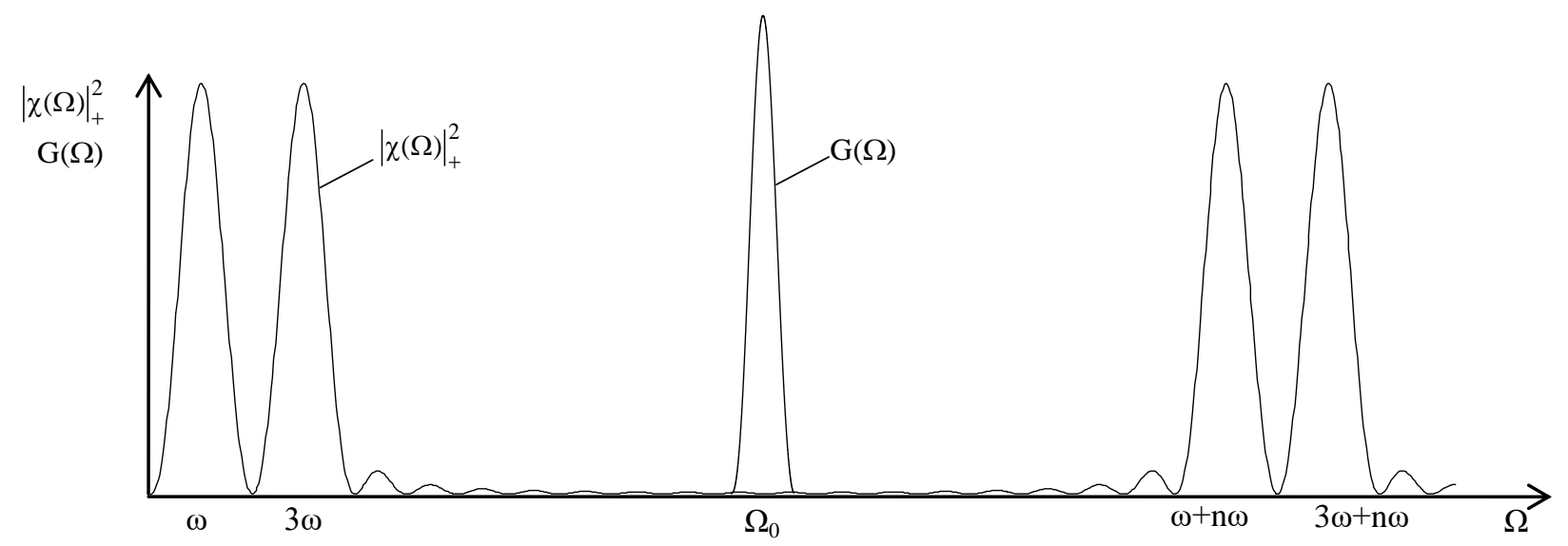

Fig. 6. The interference spectrum is located from the frequencies $3 \omega+n \omega$

In this case, from relation (31) we obtain

$$
\begin{array}{cc}
<\left(\Delta N_{\xi}\right)^{2}>_{1} \leq \frac{U^{2} \mid \chi\left(\left.\Omega_{m}\right|^{2}\right.}{n^{2}} \int_{-\infty}^{\infty} G_{i}(\Omega) d \Omega, \\
\text { Or } \quad<\left(\Delta N_{\xi}\right)^{2}>_{1}=\frac{U_{m}^{2} \sigma_{i}^{2}}{n^{2}}\left|\chi\left(\Omega_{m}\right)\right|^{2},
\end{array}
$$

where $\left|\chi\left(\Omega_{m}\right)\right|^{2}$ is the highest value of the function $|\chi(\Omega)|^{2}$ in the area occupied by the interference spectrum.

If the interference spectrum $\xi_{u}(t)$ is located in the same frequency region as the interference spectrum $\xi_{i}(t)$, then, similarly to expression (64), we have

$$
<\left(\Delta N_{\xi}\right)^{2}>_{2}=\frac{I_{m}^{2} \sigma_{u}^{2}}{n^{2}}\left|\chi\left(\Omega_{m}\right)\right|^{2} .
$$

Then the estimate of the variance of the power measurement error

$$
\begin{gathered}
<\left(\Delta N_{\xi}\right)^{2}>=<\left(\Delta N_{\xi}\right)^{2}>+<\left(\Delta N_{\xi}\right)^{2}>_{2}= \\
=\frac{1}{n^{2}}\left(\sigma_{i}^{2} U^{2}+\sigma_{u}^{2} I^{2}\right) \mid \chi\left(\left.\Omega_{m}\right|^{2}\right.
\end{gathered}
$$

or, taking into account equality (18):

$$
<\left(\Delta N_{\xi}\right)^{2}>=\frac{\sigma_{P}^{2}}{n^{2}}\left|\chi\left(\Omega_{m}\right)\right|^{2} .
$$

For the interference immunity coefficient $\Pi$ from formula (29), substituting expressions (14) and (65) into it, we find

$$
k_{i m} \geq \frac{n^{2}}{4\left|\chi\left(\Omega_{m}\right)\right|^{2}} .
$$

9

\section{References}

1. Hajimolahoseini, H., Taban, M. and Soltanian-Zadeh, H. (2012), Extended Kalman Filter frequency tracker for nonstationary harmonic signals, Measurement, Vol. 45, pp. 126-132. https://doi.org/10.1016/j.measurement.2011.09.008.
Since $\left|\chi\left(\Omega_{m}\right)\right|^{2}<|\chi(\Omega)|^{2}=n^{2} / 16$, from relation (66) we obtain

$$
k_{i m}>1 \text {. }
$$

Thus, for the interference, the central frequency of which $\Omega_{0}$ is located far from the frequencies $\omega$, $\omega+n \omega$ and $3 \omega+n \omega$, a sufficiently high interference immunity of the method is provided.

\section{Conclusions}

Thus, as a result of the research, we can draw the following conclusions.

1. The method of frequency measurement for digital power of electrical signals meters is offered. The method is based on instantaneous power correlation processing. Such approach allows increasing noise immunity of the proposed method, and, as a consequence, its accuracy.

2. Proposed mathematical theory to estimate the variance measurement error of the power of electrical signals . Proposals have been made to reduce the error in measuring the power of electrical signals. The above analysis of the interference immunity of the correlation method for measuring power can be extended to the condition under which the interference spectra in voltage and current signals are different.

3. Similarly, it is possible to evaluate the noise immunity of the method for the condition when the noise spectrum does not overlap with the maximum of the filtering function $|\chi(\Omega)|^{2}$ near the frequencies $\omega$ and $3 \omega$, but with the maxima shifted to the high frequency region $\Omega_{k}=\omega+k n \omega$ and $\Omega_{k}^{\prime}=3 \omega+k n \omega$. 
2. Bhanu, J., Baswaraj, D., Sunitha Bigul, D. and Sastry, J. (2019), Generating Test cases for Testing Embedded Systems using Combinatorial Techniques and Neural Networks based Learning Model, International Journal of Emerging Trends in Engineering Research, Vol. 7, Is. 7, pp. 417-429. https://doi.org/10.30534/ijeter/2019/047112019.

3. Bonavolontà, F., D'Apuzzo, M., Liccardo, A. and Mieleb, G. (2016), Harmonic and interharmonic measurements through a compressed sampling approach, Measurement, Vol. 77, pp. 1-15. https://doi.org/10.1016/j.measurement.2015.08.022.

4. Kihong, S. (2019), On the Selection of Sensor Locations for the Fictitious FRF based Fault Detection Method, International Journal of Emerging Trends in Engineering Research, Vol. 7, Is. 7, pp. 569-575. https://doi.org/10.30534/ijeter/2019/277112019.

5. Chang, G. and Chen, C. (2010), Measurement techniques for stationary and time-varying harmonics, IEEE Power and Energy Society General Meeting, pp. 1-5.

6. Herasimov, S., Pavlii, V. and Tymoshchuk, O. (2019), Testing Signals for Electronics: Criteria for Synthesis, Journal of Electronic Testing, Vol. 35, Is. 148, pp. 1-9. https://doi.org/10.1007/s10836-019-05798-9.

7. Dudnik, P., Ilchuk, A. and Tatarskii, B. (2007), Multifunctional radar systems, Drofa, Moscow, 207 p.

8. Kremer, I. (2004), Spatial-temporal signal processing, Radio and Communication, Moscow, 204 p.

9. Levanon, N. and Mozeson, E. (2004), Radar signals, John Wiley \& Sons Inc., Hoboken NJ, 411 p.

10. Murphy, E. and Colm, S. (2004), All About Direct Digital Synthesis, Analog Dialogue, Vol. 8, Is. 3, pp. 1-5. Available at: www.analog.com/en/analog-dialogue/articles/all-about-direct-digital-synthesis.html.

11. Wu, X., Tian, Z., Davidson, T. and Giannakis, G. (2006), Optimal waveform design for UWB radios, IEEE Transactions on Signal Processing, Vol. 54, is. 6, pp. 2009-2021. Available at: /www.ece.mcmaster.ca/ davidson/pubs/ Wu_etal_UWB_waveform_design.pdf.

12. Rybin, Yu. (2014), Measuring Signal Generators, Theory and Design, Dordrecht, Heidelberg, London, New York, Springer, $410 \mathrm{p}$.

13. Helstrom, C. (2012), Elements of Signal Detection and Estimation, Prentice Hall, Englewood Cliffs, NJ, USA, 295 p.

14. Rybin, Yu. (2012), Barkhausen Criterion for Pulses Oscillators, International Journal of Electronics, Vol. 99, No. 11, pp. $1547-1556$.

15. Herasimov, S. Tymochko, O. and Kolomiitsev, O. (2019), Formation Analysis of Multi-Frequency Signals of Laser Information Measuring System, EUREKA: Physics and Engineering, Vol. 5, pp. 19-28. https://doi.org/10.21303/24614262.2019.00984.

16. Karimian-Azari, S., Jensen, J. and Christensen, M. (2016), Computationally efficient and noise robust DOA and pitch estimation, IEEE/ACM Transactions on Audio and Language Processing, Vol. 24, pp. 1613-1625. https://doi.org/10.1109/ TASLP.2016.2577501

17. Valenzuela, J. and Pontt, J. (2009), Real-time interharmonics detection and measurement based on FFT algorithm, Appl. Electronics, pp. 259-264.

18. Herasimov, S., Roshchupkin, E. and Kutsenko, V. (2020), Statistical analysis of harmonic signals for testing of Electronic Devices, International Journal of Emerging Trends in Engineering Research, Vol. 8(7), pp. 3791-3798. https://doi.org/ $10.30534 /$ ijeter/2020/143872020.

19. Clarke, F. (2013), Functional analysis, Calculus of Variations and Optimal Control, Springer, New York, 606 p.

20. Korn, G. and Korn, T. (2000), Mathematical Handbook for Scientists and Engineers, Dver Publications Inc, New York.

\section{Список літератури}

1. Hajimolahoseini H. Extended Kalman Filter frequency tracker for nonstationary harmonic signals / H. Hajimolahoseini, M. Taban, H. Soltanian-Zadeh // Measurement. - 2012. - Vol. 45. - P. 126-132. https://doi.org/10.1016/ j.measurement.2011.09.008.

2. Generating Test cases for Testing Embedded Systems using Combinatorial Techniques and Neural Networks based Learning Model / J. Bhanu, D. Baswaraj, D. Sunitha Bigul, J. Sastry // International Journal of Emerging Trends in Engineering Research. - 2019. - Vol. 7. - Is. 7. - P. 417-429. https://doi.org/10.30534/ijeter/2019/047112019.

3. Harmonic and interharmonic measurements through a compressed sampling approach / F. Bonavolontà, M. D'Apuzzo, A. Liccardo, G. Mieleb // Measurement. - 2016. - Vol. 77. - P. 1-15. https://doi.org/10.1016/j.measurement.2015.08.022.

4. Kihong S. On the Selection of Sensor Locations for the Fictitious FRF based Fault Detection Method / S. Kihong // International Journal of Emerging Trends in Engineering Research. - 2019. - Vol. 7. - Is. 7. - P. 569-575. https://doi.org/ $10.30534 /$ ijeter/2019/277112019.

5. Chang G. Measurement techniques for stationary and time-varying harmonics / G. Chang, C. Chen // IEEE Power and Energy Society General Meeting. - 2010. - P. 1-5.

6. Herasimov S. Testing Signals for Electronics: Criteria for Synthesis / S. Herasimov, V. Pavlii, O. Tymoshchuk // Journal of Electronic Testing. - 2019. - Vol. 35. - Is. 148. - P. 1-9. https://doi.org/10.1007/s10836-019-05798-9.

7. Dudnik P. Multifunctional radar systems / P. Dudnik, A. Ilchuk, B. Tatarskii. - Moscow: Drofa, 2007. - 207 p.

8. Kremer I. Spatial-temporal signal processing / I. Kremer. - Moscow: Radio and Communication, 2004. - 204 p.

9. Levanon N. Radar signals / N. Levanon, E. Mozeson. - Hoboken NJ: John Wiley \& Sons Inc., 2004, - 411 p.

10. Murphy E. (2004), All About Direct Digital Synthesis / E. Murphy, S. Colm // Analog Dialogue. - 2004. - Vol. 8. - Is. 3. P. 1-5. Available at: www.analog.com/en/analog-dialogue/articles/all-about-direct-digital-synthesis.html.

11. Optimal waveform design for UWB radios / X. Wu, Z. Tian, T. Davidson, G. Giannakis // IEEE Transactions on Signal Processing. - 2006. - Vol. 54. - Is. 6. - P. 2009-2021. Available at: http://www.ece.mcmaster.ca/ davidson/pubs/ Wu_etal_UWB_waveform_design.pdf. 
12. Rybin Yu. Measuring Signal Generators, Theory and Design / Yu. Rybin. - Dordrecht, Heidelberg, London, New York, Springer, 2014. -410

13. Helstrom C. Elements of Signal Detection and Estimation / C. Helstrom. - NJ: Prentice Hall, Englewood Cliffs, USA, 2012. $-295 \mathrm{p}$.

14. Rybin Yu. (2012), Barkhausen Criterion for Pulses Oscillators / Yu. Rybin // International Journal of Electronics. 2012. - Vol. 99, No. 11. - P. 1547-1556.

15. Herasimov S. Formation Analysis of Multi-Frequency Signals of Laser Information Measuring System / S. Herasimov, O. Tymochko, O. Kolomiitsev // EUREKA: Physics and Engineering. - 2019. - Vol. 5. - P. 19-28. https://doi.org/ 10.21303/2461-4262.2019.00984.

16. Karimian-Azari S. Computationally efficient and noise robust DOA and pitch estimation / S. Karimian-Azari, J. Jensen, M. Christensen // IEEE/ACM Transactions on Audio and Language Processing. - 2016. - Vol. 24. - P. 1613-1625. https://doi.org/10.1109/TASLP.2016.2577501.

17. Valenzuela J. Real-time interharmonics detection and measurement based on FFT algorithm / J. Valenzuela, J. Pontt // Appl. Electronics. - 2009. - P. 259-264.

18. Herasimov S. Statistical analysis of harmonic signals for testing of Electronic Devices / S. Herasimov, E. Roshchupkin, V. Kutsenko // International Journal of Emerging Trends in Engineering Research. - 2020. - Vol. 8 (7). - P. $3791-3798$. https://doi.org/10.30534/ijeter/2020/143872020.

19. Clarke F. Functional analysis, Calculus of Variations and Optimal Control / F. Clarke. - New York: Springer, 2013. $606 \mathrm{p}$.

20. Korn G. Mathematical Handbook for Scientists and Engineers / G. Korn, T. Korn. - New York: Dver Publications Inc., 2000.

Received by Editorial Board 13.08.2020

Signed for Printing 15.09.2020

\section{Відомості про авторів:}

\section{Дакі Олена Анатоліївна}

доктор технічних наук доцент

Державного університету інфраструктури та технологій,

Київ, Україна

https://orcid.org/0000-0003-3932-462X

\section{Герасимов Сергій Вікторович}

доктор технічних наук професор

Харківського національного університету

Повітряних Сил ім. І. Кожедуба,

Харків, Україна

https://orcid.org/0000-0003-1810-0387

\section{Зубрицький Григорій Миколайович}

кандидат технічних наук доцент

провідний науковий співробітник

Харківського національного університету

Повітряних Сил ім. І. Кожедуба,

Харків, Україна

https://orcid.org/0000-0002-9577-5268

\section{Information about the authors:}

\section{Olena Daki}

Doctor of Technical Sciences Associate Professor of State University of Infrastructure and Technology, Kyiv, Ukraine https://orcid.org/0000-0003-3932-462X

\author{
Sergey Herasimov \\ Doctor of Technical Sciences Professor \\ of Ivan Kozhedub Kharkiv National \\ Air Force University, \\ Kharkiv, Ukraine \\ https://orcid.org/0000-0003-1810-0387
}

\author{
Hryhorii Zubrytskyi \\ Candidate of Technical Sciences Associate Professor \\ Lead Research \\ of Ivan Kozhedub Kharkiv National \\ Air Force University, \\ Kharkiv, Ukraine \\ https://orcid.org/0000-0002-9577-5268
}

\section{ЦИФРОВИЙ КОРЕЛЯЦІЙНИЙ МЕТОД ВИМІРЮВАННЯ ПОТУЖНОСТІ}

О.А. Дакі, С.В. Герасимов, Г.М. Зубрицький

В статті запропонований метод вимірювання потужності електричних сигналів, який трунтується на співвідношенні для виміряного (дійсного) значення потужності. Метою статті є розробка методу цјифрової кореляції для вимірювання потужності та очінки методичної похибки такого вимірювання.

Теоретично алгоритм вимірювання потужності запропонованим циифровим кореляційним методом засновано на переході від інтеграла до суми, щя вносить методичну похибку дискретизачії. Для визначення методичної похибки дискретизаиії та перешкодозахищеності розробленого методу обчислені оцінки дисперсії перешкоди вимірюваної потужності на вході та виході цифрового кореляційного вимірювача, знайдені для них відносини сигнал / перешкода. 
Обчислені відносини сигнал / перешкода на вході та виході запропонованого циифрового кореляційного вимірювача потужності для оиінки його динамічного діапазону вимірювань. Показано, щэо методична похибка дискретизації та перешкодозахищеність иифрового корелячійного методу вимірювання потужності визначається кількістю точок їх дискретизації.

Обтрунтовано, щуо вузькосмугові фільтруючі властивості запропонованої функції коефіцієнта передачі перешкоди по потужності від входу до виходу на частоті електричного сигналу пояснюють перевагу кореляиійного методу вимірювання потужності, що складається в його високій перешкодозахищеності. Доведено, що кількісні оцінки перешкодозахищеності методу залежать від розподілу енергії по спектру перешкоди. Такі оцінки будуть визначатися співвідношенням між шириною смуги спектра перешкоди і шириною запропонованої фільтруючої функиії.

Розглянуто три варіанти перешкодозахищеності кореляційного методу вимірювання потужності електричних сигналів: перешкода широкосмугова; перешкода вузькосмугова; перешкода вузькосмугова, а ії иентральна частота знаходиться поблизу частоти електричного сигналу.

Наведений аналіз перешкодозахищеності корелячійного методу вимірювання потужності можна поширити на умову, за якої спектри перешкод в сигналах напруги і струму мають різний характер.

Ключові слова: метод, цифрові вимірювачі потужності, перешкодозахищеність, точність.

\section{ЦИФРОВОЙ КОРРЕЛЯЦИОННЫЙ МЕТОД ИЗМЕРЕНИЯ МОЩНОСТИ}

\section{Е.А. Даки, С.В. Герасимов, Г.Н. Зубрицкий}

Предложен метод измерения частотных преобразований в цифровых измерителях мощности электрических сигналов. Метод основан на обработке коррелячии мгновенных значений мощңности. Такой подход позволяет повысить помехозащищенность предлагаемого метода и, как следствие, его точность. Предложена математическая теория для оценки дисперсии погрешности измерения мощности электрических сигналов. Внесены предложения по снижению погрешности измерения мощности электрических сигналов. Анализ помехоустойчивости корреляционного метода измерения мощности может быть расширен до условия, при котором спектры помех в сигналах напряжения и тока различные.

Ключевые слова: метод, цифровые измерители мощности, помехозащищенность, точность. 